2016

\title{
Indigenous Territorial Rights in the Common Law
}

Kent McNeil

Osgoode Hall Law School of York University, kmcneil@osgoode.yorku.ca

Follow this and additional works at: http:// digitalcommons.osgoode.yorku.ca/olsrps

Part of the Indian and Aboriginal Law Commons

\section{Recommended Citation}

McNeil, Kent, "Indigenous Territorial Rights in the Common Law" (2016). Osgoode Legal Studies Research Paper Series. 173. http://digitalcommons.osgoode.yorku.ca/olsrps/173 


\title{
OSGOODE HALL LAW SCHOOL \\ LEGAL STUDIES RESEARCH PAPER SERIES
}

Research Paper No. 62

Volume 12, Issue 13, 2016

\section{Indigenous Territorial Rights in the Common Law}

\author{
Kent McNeil
}

This paper can be downloaded free of charge from:

http://ssrn.com/abstract=2790966

\begin{abstract}
Further information and a collection of publications from the Osgoode Hall Law School Legal Studies Research Paper Series can be found at:

http://www.ssrn.com/link/Osgoode-Hall-LEG.html
\end{abstract}

\section{Editors:}

Editor-in-Chief: Carys J. Craig (Associate Dean of Research \& Institutional Relations and Associate Professor, Osgoode Hall Law School, York University, Toronto)

Production Editor: Kiana Blake (Osgoode Hall Law School, York University, Toronto) 
Osgoode Legal Studies Research Paper No. 62

Vol. 12/ Issue. 13/ (2016)

\title{
Indigenous Territorial Rights in the Common Law
}

\author{
Kent McNeil
}

\begin{abstract}
:
This chapter compares Indigenous territorial rights in the United States, Canada, Australia and New Zealand thematically under four headings: the sources, nature and content, proof, and protection of Indigenous rights. The first two are closely linked, as the nature and content of Indigenous rights are determined largely by their sources. Likewise, proof of Indigenous rights also depends on their sources. The protection they are accorded in any particular nation-state depends mainly on its constitution, with recent additional protection emerging in international law.

The major premise of the chapter is that Indigenous rights are territorial, encompassing real property rights and governmental authority over a geographical space. The chapter examines these rights primarily from the perspectives of the dominant state legal systems in the four jurisdictions discussed. The author acknowledges nonetheless that Indigenous peoples have their own legal orders that govern these rights internally within their own territories. However, the focus of the analysis is on the external dimensions of Indigenous territorial rights, that is, the sources, nature, etc. of those rights vis-à-vis the rest of society, especially the settler governments.
\end{abstract}

\section{Keywords:}

Indigenous peoples, Indigenous territorial rights, Indigenous land rights

\author{
Author(s): \\ Kent McNeil \\ Osgoode Hall Law School, York University \\ E: kmcneil@osgoode.yorku.ca
}




\title{
Indigenous Territorial Rights in the Common Law \\ (C) Kent McNeil \\ Osgoode Hall Law School \\ York University \\ Toronto, Canada \\ February, 2015
}

\begin{abstract}
This chapter compares Indigenous territorial rights in the United States, Canada, Australia and New Zealand thematically under four headings: the sources, nature and content, proof, and protection of Indigenous rights. The first two are closely linked, as the nature and content of Indigenous rights are determined largely by their sources. Likewise, proof of Indigenous rights also depends on their sources. The protection they are accorded in any particular nation-state depends mainly on its constitution, with recent additional protection emerging in international law.

The major premise of the chapter is that Indigenous rights are territorial, encompassing real property rights and governmental authority over a geographical space. The chapter examines these rights primarily from the perspectives of the dominant state legal systems in the four jurisdictions discussed. The author acknowledges nonetheless that Indigenous peoples have their own legal orders that govern these rights internally within their own territories. However, the focus of the analysis is on the external dimensions of Indigenous territorial rights, that is, the sources, nature, etc. of those rights vis-à-vis the rest of society, especially the settler governments.
\end{abstract}

This chapter is entitled 'Indigenous territorial rights' rather than 'Indigenous land rights' because the rights of Indigenous peoples are rights to territory that encompass, but are not limited to, land rights (McNeil, 2013b). ${ }^{1}$ The term 'land rights' generally means property rights, whereas I use the term 'territorial rights' to include jurisdiction (governmental

\footnotetext{
${ }^{1}$ In this chapter, the terms 'Indigenous' and 'Aboriginal' are used synonymously, depending on context. While I prefer 'Indigenous', 'Aboriginal' is unavoidable when discussing Canada, as s35(1) of the Constitution Act, 1982, Schedule B to the Canada Act 1982, c11 (UK), recognizes and affirms "the existing aboriginal and treaty rights of the aboriginal peoples of Canada." In the United States, the term 'Indian' is still common, and so will be used in this chapter in appropriate contexts.
} 
authority) over a geographical area as well as property rights to lands therein. In the federal nation-states of Australia, Canada and the United States - the countries, along with New Zealand, discussed in this chapter - the states and provinces exercise jurisdiction over their territories and have property rights in some lands. The jurisdictional dimension of their territorial rights empowers them to enact and administer laws governing, not just their own property, but the property of individuals and corporations within the state or province.

Similarly, I regard the territorial rights of Indigenous peoples as including both jurisdiction over and property in the lands within their territories. As discussed below, the jurisdictional aspect of these peoples' rights has been legally acknowledged in the United States since at least the 1830s, recognized in the Māori version of the Treaty of Waitangi in New Zealand in 1840, tentatively accepted in Canada during the last 20 years or so, but denied in Australia ever since British colonization began in 1788.

In this chapter, Indigenous territorial rights are discussed primarily from the perspective of the dominant legal systems of these four nation-states. I nonetheless acknowledge that Indigenous peoples have their own legal orders that can and should be used to determine the nature and content of their rights (Napoleon, 2009; Borrows, 2010; Jones, 2013). Where land rights are concerned, these legal orders are internal to the Indigenous people in question. Using these legal orders to determine their land rights visà-vis the governments that have imposed their authority on them is problematic, as the example of Australia, discussed below, demonstrates. A territorial approach can mean that Indigenous rights are determined externally by what some have called intersocietal law (Slattery, 1991; Walters, 2006), conceived of as the law that developed and is 
continuing to develop to govern the relationship between Indigenous and non-Indigenous governments within internationally recognized nation-states. ${ }^{2}$ At the jurisdictional level, relations between these governments, and their authority and rights vis-à-vis one another, should be determined, not by the internal law of either government, but by this intersocietal law. The situation is similar to the relationship of the national government with state or provincial governments in federal systems: it is governed not by federal or state/provincial law, but by the higher law of the constitution to which both are subject.

This chapter compares Indigenous territorial rights in the United States, Canada, Australia and New Zealand thematically under four headings: the sources, nature and content, proof, and protection of Indigenous rights. The first two are closely linked, as the nature and content of Indigenous rights are determined largely by their sources. Likewise, proof of Indigenous rights also depends on their sources. The protection they are

\footnotetext{
${ }^{2}$ International recognition does not mean nation-state sovereignty over Indigenous peoples is legitimate; it only means that nation-states in the international community acknowledge this sovereignty in their system of international law. This sovereignty may not be recognized in Indigenous legal systems. The legitimacy of nation-state sovereignty cannot be assessed solely from the perspective of international law, as Indigenous peoples (prior to the United Nations Declaration of the Rights of Indigenous Peoples) had no part in creating that law and have generally not consented to its application to their territories (McNeil, 2013a).
} 
accorded in any particular nation-state depends mainly on its constitution, with recent additional protection emerging in international law. ${ }^{3}$

1. Sources of Indigenous territorial rights

The highest courts in the nation-states considered here have identified four legal orders as potentially relevant for determining the sources of Indigenous territorial rights: (1) natural law, especially as expressed in the law of nations; (2) the common law; (3) Indigenous law; and (4) positive law enactments such as proclamations and statutes. The United States Supreme Court has relied mainly on the first of these. In Canada the Supreme Court has focused more on the common law and Indigenous law. The highest courts in Australia and New Zealand have relied on Indigenous law, but not in the same way as the Canadian Supreme Court. Statutes have been positive sources of limited Indigenous land rights in all four nation-states, examples being the Aboriginal Land Rights (Northern Territory) Act ${ }^{4}$ in Australia and the Metis Settlements Act ${ }^{5}$ in Canada. As statutory land rights are generally local and defined by positive enactment rather than broader legal principles, they will not be discussed here.

\footnotetext{
${ }^{3}$ I will not discuss Indigenous peoples' rights in international law, as this is dealt with in Federico Lenzerini's chapter.

${ }^{4}$ Cth, No 191 of 1976.

${ }^{5}$ RSA 2000, cM-14.
} 
Looking first at American law, Chief Justice Marshall delivered his seminal decision on the matter in 1823 in Johnson $v$ M'Intosh, ${ }^{6}$ a case involving the validity of alienation of Indian lands to a private purchaser prior to the American Revolution. Marshall regarded the Indian tribes as independent nations with complete sovereignty and ownership of lands in the territories occupied by them prior to European colonization. He then created the doctrine of discovery, a supposed principle of the law of nations that he thought had been agreed upon by all the colonizing European powers to avoid disputes among themselves over their territorial claims in North America. ${ }^{7}$ Discovery, he said, 'gave title to the government by whose subjects, or by whose authority, it was made, against all other European governments, which title might be consummated by possession. ${ }^{8}$ On the impact of discovery on the Indian nations, Marshall observed:

They were admitted to be the rightful occupants of the soil, with a legal as well as just claim to retain possession of it, and to use it according to their own discretion; but their rights to complete sovereignty, as independent nations, were necessarily

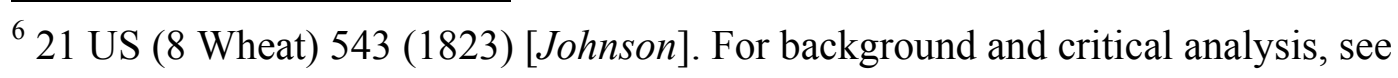
Robertson, 2005.

${ }^{7}$ Marshall was undoubtedly wrong about this, as subsequent research has revealed no such agreement. On the contrary, the European powers each relied on justifications for colonial acquisitions that served their own interests and disparaged justifications that supported their rivals' claims. See Lindley, 1926; Goebel, 1927: 47-119; Seed, 1995; Slattery, 2005.

${ }^{8}$ Johnson, above n6, 573. 
diminished, and their power to dispose of the soil at their own will, to whomsoever they pleased, was denied by the original fundamental principle, that discovery gave exclusive title to those who made it. ${ }^{9}$

This passage might be interpreted as meaning that discovery itself reduced Indian territorial rights, but that reading was disavowed by Marshall himself in 1832 in Worcester $v$ Georgia (Secher, 2014: 51-58). ${ }^{10}$ There he said that discovery

... was an exclusive principle which shut out the right of competition among those who had agreed to it; not one which could annul the previous rights of those who had not agreed to it. It regulated the right given by discovery among the European discoverers, but could not affect the rights of those already in possession, either as aboriginal occupants, or as occupants by virtue of a discovery made before the memory of man. ${ }^{11}$

In other words the doctrine of discovery applied only among the European powers that had agreed to it, not to the Indian nations that had not. ${ }^{12}$ For European powers to acquire

${ }^{9}$ Ibid, 574. For critiques, see Deloria, 1985: 85-111; Williams, 1990: 308-17; Wilkins and Lomawaima, 2001: 19-63; Miller et al, 2010.

${ }^{10} 31$ US (6 Pet) 515 (1832) [Worcester].

${ }^{11} \mathrm{Ibid}, 544$.

${ }^{12}$ This is consistent with the international law principle that treaties bind only the parties: see Direct United States Cable Company v Anglo-American Telegraph Company (1877), 
sovereignty over Indian territories and a right of preemption of their lands, something more was required: an actual taking of possession, which could occur as a result of either treaty or conquest (McNeil, 2000a: 11-14). ${ }^{13}$

European sovereignty was thus acquired by a combination of a supposed principle of the law of nations and the actual taking of possession by the colonizing nation-state. This acquisition reduced the complete independence of the Indian nations, leading Marshall CJ to conclude that, once included within the territorial limits of the United States, they were 'domestic dependent nations'. ${ }^{14}$ He nonetheless held that they retained their internal independence and lands within the territories that had not been ceded by them or taken by force. ${ }^{15}$ Marshall's pronouncements on this matter remain the fundamental American law on Indian territorial rights, ${ }^{16}$ subject to the so-called plenary

2 App Cas 394 (PC) at 421; Clipperton Island Case, (1932) 26 AJIL 390 at 394; McNair, 1965: 412; Brownlie, 2003: 598-600.

${ }^{13}$ In Worcester, above n10, 547, 549, Marshall played down conquest, finding instead that the British and American practice was to enter into treaties. Compare Johnson, above n6, 589-92.

${ }^{14}$ Cherokee Nation v Georgia, 30 US (5 Pet) 1 at 17 (1831) [Cherokee Nation].

${ }^{15}$ Ibid; Johnson, above n6, 593; Worcester, above n10, especially 555-61.

${ }^{16}$ United State v Mazurie, 419 US 544 at 557 (1975); United States v Wheeler, 435 US 313 at 322-23 (1978) [Wheeler]; Santa Clara Pueblo v Martinez, 436 US 49 (1978); United States v Lara, 541 US 193 (2004) [Lara]. See Newton, 2012: §4.01[1][a]. 
power of Congress to reduce or even take away these rights ${ }^{17}$ and to judicially constructed limitations on Indian nations' authority over nonmembers in their territories. $^{18}$

Indian territorial rights in what is now the United States therefore predated European acquisition of sovereignty and continued after the creation of the American Republic, in the reduced form described by Chief Justice Marshall (Newton, 2012: $\S 15.04[2])$. But what exactly is the source of these rights? While acknowledging that the Indian nations have their own internal systems of law, ${ }^{19}$ Marshall did not seem to regard those legal systems as the source of their territorial rights. Instead, he viewed natural law, which prior to the rise of legal positivism in the $19^{\text {th }}$ century was the generally accepted basis for the law of nations, as the source. In Worcester $v$ Georgia, he said that the 'Indian nations had always been considered as distinct, independent political communities, retaining their original natural rights, as the undisputed possessors of the soil, from time immemorial'. ${ }^{20}$ These rights include not just property rights to land, but

${ }^{17}$ See United States v Kagama, 118 US 375 (1986); Lone Wolf v. Hitchcock, 187 US 553 (1903). For critiques, see Wilkins and Lomawaima, 2001: 98-116; Clinton, 2002.

${ }^{18}$ See Oliphant v Squamish Indian Tribe, 435 US 191 (1978); Montana v United States, 450 US 544 (1981); Strate v A-1 Contractors, 520 US 438 (1997); Nevada v Hicks, 533

US 353 (2001); Plains Commercial Bank v Long Family Land \& Cattle Co., 554 US 316 (2008). For critiques, see Duthu, 1994; Frickey, 1999; LaVelle, 2006; Levy, 2013.

${ }^{19}$ See Johnson, above n6, 593; Worcester, above n10, 542-43.

${ }^{20}$ Worcester, above n10, 559 (emphasis added). See also 560, where he referred to the 'original right, possessed by the occupants of every country', and quotation at n11 above. 
governance rights over territory. ${ }^{21}$ In American law, the source of Indian territorial rights therefore appears to be possession and the effect given to it by natural law. ${ }^{22}$

In Canada the source of Indigenous territorial rights is also possession, though the Supreme Court has not yet pronounced on whether this possession entails jurisdiction as well as property rights. The leading case is Delgamuukw $v$ British Columbia, ${ }^{23}$ decided in 1997. It involved a claim to Aboriginal title and self-government by the Gitksan and Wet'suwet'en Nations in central British Columbia. The Supreme Court did not rule on the self-government issue, nor did it decide whether Aboriginal title had been proven, as problems with the pleadings and mistreatment of oral history evidence by the trial judge necessitated a new trial (the case has not been retried). Chief Justice Lamer nonetheless wrote a lengthy judgment on the source, content, proof and constitutional protection of Aboriginal title.

Regarding the source, Lamer CJ stated that, although it was once thought that Aboriginal title is sourced in the Royal Proclamation of $1763,{ }^{24}$ it is now clear that it

${ }^{21}$ Ibid, 559, 561.

${ }^{22}$ Likewise in international law, possession through effective control, including physical presence and exercise of jurisdiction, is the source of title to previously unoccupied and unclaimed territory. See Island of Palmas Case, (1928) 2 RIAA 829; Legal Status of Eastern Greenland Case, (1933) 2 PCIJ, Series A/B, No 43; Minquiers and Ecrehos Case, 1953 ICJR 47.

${ }^{23}$ [1997] 3 SCR 1010 [Delgamuukw].

${ }^{24}$ Reproduced in RSC 1985, App II, No 1. Among other things, this Proclamation, issued by George III, provided protections for Indian lands and established a process for 
... arises from the prior occupation of Canada by aboriginal peoples. That prior occupation, however, is relevant in two different ways, both of which illustrate the sui generis nature of aboriginal title. The first is the physical fact of occupation, which derives from the common law principle that occupation is proof of possession in law.... What makes aboriginal title sui generis is that it arises from possession before the assertion of British sovereignty, whereas normal estates, like fee simple, arise afterward.... This idea has been further developed in Roberts v. Canada, [1989] 1 S.C.R. 322, where this Court unanimously held at $\mathrm{p}$. 340 that 'aboriginal title pre-dated colonization by the British and survived British claims of sovereignty'.... What this suggests is a second source for aboriginal title - the relationship between common law and pre-existing systems of aboriginal law. $^{25}$

While this passage suggests that common law possession and Aboriginal law are two distinct sources, later in his judgment Lamer seems to have combined them: Aboriginal title, he said, arises from exclusive occupation of land immediately prior to the British Crown's assertion of sovereignty. This occupation can be shown by evidence of physical presence and use, and by reliance on Aboriginal law: 'if, at the time of sovereignty, an aboriginal society had laws in relation to land, those laws would be

surrendering them to the Crown. See St. Catherine's Milling and Lumber Company v The Queen, (1888) 14 App Cas 46 (PC).

${ }^{25}$ Delgamuukw, above n23, para 114. 
relevant to establishing the occupation of lands which are the subject of a claim for aboriginal title. Relevant laws might include, but are not limited to, a land tenure system or laws governing land use. ${ }^{, 6}$ Use of Aboriginal law as evidence of occupation has been recently affirmed by the Supreme Court in Tsilhqot'in Nation v British Columbia, ${ }^{27}$ discussed below in relation to proof.

Indigenous land rights in Canada are not limited to Aboriginal title. The Supreme Court has upheld resource use rights, such as the right to hunt, fish, or harvest timber for domestic purposes on specific lands, ${ }^{28}$ that arise, not from exclusive occupation of land, but from practices, customs and traditions that were integral to distinctive Indigenous cultures at the time of contact with Europeans ${ }^{29}$ or, in the case of the Métis, effective

${ }^{26} \mathrm{Ibid}$, para 148. It is doubtful that Lamer intended to dismiss the possibility of Aboriginal law being a distinct source in addition to evidence of occupation. The passage from Roberts $v$ Canada that he quoted with approval (text at $\mathrm{n} 25$ above) apparently refers to situations where Aboriginal peoples had land rights under their own laws that continued after Crown sovereignty. See McNeil and Yarrow, 2007: 204-11. 27 [2014] 2 SCR 257 [Tsilhqot'in Nation].

${ }^{28}$ See $R v$ Adams, [1996] 3 SCR 101; $R$ v Powley, [2003] 2 SCR 207 [Powley]; $R v$ Sappier; R v Gray, [2006] 2 SCR 686 [Sapper/Gray].

${ }^{29} R v$ Van der Peet [1996] 2 SCR 507 [Van der Peet]. For critiques, see Borrows, 1997; Barsh and Henderson, 1997; Cheng, 1997. 
European control. ${ }^{30}$ Relevant customs and traditions can include, but are not limited to, Aboriginal laws. $^{31}$

In Australia Indigenous law has been used more directly as the basis for Indigenous land rights. In Mabo v Queensland [No 2], ${ }^{32}$ decided in 1992, the High Court for the first time acknowledged the existence of Native title (the Australian term for Indigenous land rights), thereby reversing two centuries of denial (Russell, 2005; KeonCohen, 2011; Secher, 2014). The Court issued an order declaring that the Meriam people of the Murray Islands in the Torres Strait off Queensland's Cape York 'are entitled as against the whole world to possession, occupation, use and enjoyment of the lands of the Murray Islands. ${ }^{33}$ On Native title's source, Justice Brennan, delivering the principal judgment, stated that it 'has its origin in and is given its content by the traditional laws acknowledged by and the traditional customs observed by the indigenous inhabitants of a territory. ${ }^{34}$ The Court thus adopted a principle of British colonial and international law, commonly called the doctrine of continuity, whereby the property rights of local peoples under their own legal systems are presumed to have continued and become enforceable in

${ }^{30}$ Powley, above n28. The Métis, who originated as a distinct people mainly from intermarriage of Indigenous women and European fur-traders, are one of the three Aboriginal peoples, along with Indians and Inuit, whose Aboriginal rights are recognized and affirmed by s35 of the Constitution Act, 1982, above n1. See Chartrand, 2002.

${ }^{31}$ See Sappier/Gray, above n28, para 45.

32 (1992) 175 CLR 1 [Mabo].

${ }^{33}$ Ibid, Court Order, 217.

${ }^{34}$ Ibid, 58. 
common law courts after Crown acquisition of sovereignty over a colonial territory

(O’Connell, 1967: I, 237-50; Walters, 1999; Barsh, 2004.).

The justices could not, however, have based the communal title of the Meriam people on Meriam law, as Justice Moynihan, the judge who had made the factual findings upon which the High Court's decision was based, had 'found that there was apparently no concept of public or general community ownership among the people of Murray Island, all the land on Murray Island being regarded as belonging to individuals or groups. ${ }^{, 35}$ According to Brennan J, the communal title was based instead on possession, giving rise to a proprietary interest in the Meriam people as a whole that, along with the interests based on Meriam law, continued after Crown assertion of sovereignty:

If it be necessary to categorize an interest in land as proprietary in order that it survive a change in sovereignty, the interest possessed by a community that is in exclusive possession of land falls into that category. Whether or not land is owned by individual members of a community, a community which asserts and asserts effectively that none but its members has any right to occupy or use the land has an interest in the land that must be proprietary in nature: there is no other proprietor. $^{36}$

\footnotetext{
${ }^{35}$ Ibid, 22.

${ }^{36} \mathrm{Ibid}, 51$.
} 
Unfortunately, this aspect of Brennan J's decision was ignored by the Australian Parliament when it enacted the Native Title Act 1993 (Cth), a complex statutory regime designed in part to give effect to the Mabo decision. Section 223(1) of the Act contains a definition of Native title that reflects only its Indigenous law source, disregarding Brennan's possessory explanation for the Meriam people's communal title that must have been the basis for the Court's order quoted above (McNeil, 2012a):

223 (1) The expression native title or native title rights and interests means the communal, group or individual rights and interests of Aboriginal peoples or Torres Strait Islanders in relation to land or waters, where:

(a) the rights and interests are possessed under the traditional laws acknowledged, and the traditional customs observed, by the Aboriginal peoples or Torres Strait Islanders; and

(b) the Aboriginal peoples or Torres Strait Islanders, by those laws and customs, have a connection with the land or waters; and

(c) the rights and interests are recognised by the common law of Australia.

The High Court has since relied on this statutory definition and required evidence of Indigenous laws and customs at the time of Crown acquisition of sovereignty to establish 
land rights, as well as requiring proof that the laws and customs have been substantially maintained up to the present day. ${ }^{37}$

In New Zealand Māori territorial rights were acknowledged at the outset of formal British colonization by the 1840 Treaty of Waitangi. Continuing Māori territorial jurisdiction is provided for in the Māori version, though not explicitly in the English version (Ruru, 2009: 114). Land rights are guaranteed in both. In English, the Māori have 'the full exclusive and undisturbed possession of their Lands and Estates Forests Fisheries and other properties. ${ }^{38}$ In the 1847 decision of the New Zealand Supreme Court in The Queen $v$ Symonds, ${ }^{39}$ Justice Chapman observed that 'in solemnly guaranteeing the Native title ... the Treaty of Waitangi, confirmed by the Charter of the Colony, does not assert either in doctrine or in practice any thing new and unsettled. ${ }^{40}$ The Privy Council approved of this decision in Nireaha Tamaki v Baker, ${ }^{41}$ rejecting Chief Justice Prendergast's opinion in Wi Parata $v$ Bishop of Wellington ${ }^{42}$ that 'there is

${ }^{37}$ See Fejo v Northern Territory, (1998) 195 CLR 128; Commonwealth v Yarmirr, (2001) 208 CLR 1; Western Australia v Ward, (2002) 213 CLR 1 [Ward]; Members of the Yorta Yorta Community v Victoria, (2002) 214 CLR 422 [Yorta Yorta]. For critical analysis, see Young, 2008; Strelein, 2009.

${ }^{38}$ Art 2. The Treaty is reproduced in the Treaty of Waitangi Act, NZS 1975, No 114, First Schedule. See McHugh, 1991; Orange, 2004; Belgrave et al, 2005.

${ }^{39}$ [1840-1932] NZPCC 387.

${ }^{40}$ Ibid, 390.

${ }^{41}$ [1901] AC 561 [Nireaha Tamaki].

${ }^{42}$ (1877) 3 NZ Jur (NS) SC 72. 
no customary law of the Maoris of which the Courts of Law can take cognizance'. ${ }^{43}$ The Privy Council said instead that the regime put in place by statute to give effect to Māori title 'plainly assumes the existence of a tenure of land under custom and usage which is either known to lawyers or discoverable by them by evidence'. ${ }^{44}$ The New Zealand Court of Appeal recently affirmed in Attorney-General $v$ Ngati Apa ${ }^{45}$ that Māori land rights are sourced in Māori custom and usage, or tikanga Māori (Ruru, 2009: 127-28).

The doctrine of continuity of pre-existing Indigenous land rights has thus been applied less rigidly in New Zealand than in Australia (Young, 2008: 167-200). The source of Māori land rights is not just traditional laws and customs, but also practice and usage, as is the case for Aboriginal rights apart from title in Canada (McNeil, 2007a: 8789). This approach avoids the problem faced by Indigenous claimants in Australia of having to prove that they had a normative system prior to Crown sovereignty that provided them with 'rights' recognizable as such by Australian judges. ${ }^{46}$

2. The nature and content of Indigenous territorial rights

As mentioned earlier, the nature and content of Indigenous territorial rights are determined largely by their source. Where the source is possession and application of

\footnotetext{
${ }^{43}$ Nireaha Tamaki, above n41, 577. See Secher, 2014: 59-75.

${ }^{44}$ Nireaha Tamaki, above n41, 577.

${ }^{45}$ [2003] 3 NZLR 643 (CA) [Ngati Apa].

${ }^{46}$ See Yorta Yorta, above n37. For critiques, see McNeil, 2001b; Young, 2008.
} 
natural or common law, as in the United States and Canada, the result is different from Australia and New Zealand where Indigenous law is relied upon.

In the United States, we have seen that the Indian nations' complete independence and ownership of lands prior to European colonization flowed from their possession of territories 'either as aboriginal occupants, or as occupants by virtue of a discovery made before the memory of man. ${ }^{47}$ After colonization and inclusion within the United States, they retained both their jurisdiction over and land rights within the territories held by them as 'domestic dependent nations'. ${ }^{48}$ The jurisdictional dimension of their territorial rights amounts to residual sovereignty: the Indian nations have inherent governmental authority to the extent that it has not been diminished by colonization and inclusion within the United States, treaties, Acts of Congress, and judicial decisions (Newton, 2012: $§ 4.01)$. Their land rights are all-encompassing, amounting to a collective right to exclusive possession, use and enjoyment of their lands, including rights to standing timber and subsurface rights to minerals. ${ }^{49}$ However, while the Indian nations can make laws providing for the creation of individual or other property rights within their

${ }^{47}$ Worcester, above n10, 544.

${ }^{48}$ Cherokee Nation, above n14; Worcester, above n10. See Norgren, 1996.

${ }^{49}$ See United States $v$ Shoshone Tribe, 304 US 111 at 115-18 (1938); United States $v$ Klamath and Moadoc Tribes, 304 US 119 at 122-23 (1938); Otoe and Missouria Tribe v United States, 131 F Supp 265 at 290-91 (1955), cert denied 350 US 848 (1955); United States v Northern Paiute Nation, 393 F 2d 786 at 796 (1968); United States ex rel Chunie $v$ Ringrose, 788 F 2d 638 at 642 (1986). 
territories, they can only alienate their collectively-held lands so as to remove them from their territory and jurisdiction by surrendering them to the United States. ${ }^{50}$

In Canada, the Supreme Court has held that the Aboriginal title arising from exclusive occupation at the time of the British Crown's assertion of sovereignty is a sui generis property right. ${ }^{51}$ As in the United States, Aboriginal title is a collective interest that is inalienable other than by surrender to the Crown. ${ }^{52}$ It is also a complete beneficial interest, including timber, minerals, oil and gas. ${ }^{53}$ As held by Lamer CJ in Delgamuukw, it 'encompasses the right to exclusive use and occupation of the land held pursuant to that title for a variety of purposes, which need not be aspects of those aboriginal practices, customs and traditions which are integral to distinctive aboriginal cultures'. ${ }^{54}$ It also includes authority to manage the land, ${ }^{55}$ though unlike in the United States the Supreme Court has not clarified whether this authority is governmental in nature. However, in

${ }^{50}$ Johnson, above n6. However, from 1887 to 1934, the General Allotment Act, 24 US

Stat 388, permitted creation of individual landholdings and distribution of 'surplus' Indian lands, resulting in loss of about two-thirds of tribal lands: see Otis, 1973; Prucha, 1976: 227-64.

${ }^{51}$ Delgamuukw, above n23, paras 109-15.

${ }^{52}$ Ibid, paras 113,115 . Although inalienability is usually justified as a necessary protection against exploitation, a better explanation may be that private persons cannot acquire a title that has jurisdictional dimensions: see McNeil, 2002.

${ }^{53}$ Delgamuukw, above n23, paras 116-24; Tsilhqot'in Nation, above n27, paras 67, 116.

${ }^{54}$ Delgamuukw, above n23, para 117.

${ }^{55}$ Ibid, para 115; Tsilhqot'in Nation, above n27, para 73. 
Campbell v British Columbia,${ }^{56}$ a trial court decision that was not appealed, Justice Williamson held that the decision-making authority that Aboriginal nations have over their lands must be governmental in nature, as a community needs a political structure to make collective decisions (McNeil, 2007b: 139-43). ${ }^{57}$

Unlike in the United States, Aboriginal title in Canada is subject to an inherent limit. In Delgamuukw, Lamer CJ decided that 'lands subject to aboriginal title cannot be put to such uses as may be irreconcilable with the nature of the occupation of that land and the relationship that the particular group has had with the land which together have given rise to aboriginal title in the first place. ${ }^{58}$ This judicially-created limit is designed to preserve the land for the benefit of future generations. Lamer gave this example of its application: 'if occupation is established with reference to the use of the land as a hunting ground, then the group that successfully claims aboriginal title to that land may not use it in such a fashion as to destroy its value for such a use (e.g., by strip mining it). ${ }^{59}$ In her

${ }^{56}$ [2000] 4 CNLR 1, paras 137-38 (BCSC) [Campbell].

${ }^{57}$ In House of Sga'nisim v Canada (Attorney General), [2012] 2 CNLR 82 (BCSC), Smith J followed Campbell out of comity, but also held that the Nisga'a Final Agreement, 1998, the validity of which was partially challenged in these cases, could be upheld as delegated governmental authority. Smith's decision was upheld on the latter basis, without deciding the inherent right issue: [2013] 2 CNLR 226 (BCCA).

${ }^{58}$ Delgamuukw, above n23, para 128. For critical commentary, see McNeil, 2001a: 11622.

${ }^{59}$ Delgamuukw, above n23, para 128 . He also drew an analogy to equitable waste: ibid, para 130. 
unanimous judgment in Tsilhqot'in Nation, Chief Justice McLachlin clarified that, because Aboriginal title is a collective interest held for present and future generations, it cannot be alienated, encumbered, used or developed so as to substantially deprive succeeding generations of the enjoyment and benefit of it. ${ }^{60}$ Her emphasis was more on sustainable development than on traditional uses. Moreover, she held that the inherent limit also applies to non-Aboriginal governments: as 'Aboriginal title is a group interest that inheres in present and future generations[,] ... incursions on Aboriginal title cannot be justified if they would substantially deprive future generations of the benefit of the land. ${ }^{61}$

While Aboriginal title in Canada is 'a right to the land itself' that is certainly a property right, ${ }^{62}$ it is not clear whether resource use rights such as hunting and fishing rights that do not depend on title are proprietary ${ }^{63}$ They could be analogized with profitsà-prendre, though like Aboriginal title they have been described as sui generis by the Supreme Court. ${ }^{64}$ The content of these resource use rights is determined by practices,

${ }^{60}$ Tsilhqot'in Nation, above n27, para 74,

${ }^{61} \mathrm{Ibid}$, para 86.

${ }^{62}$ Delgamuukw, above n23, para 138

${ }^{63}$ See $R$ v Sparrow, [1990] 1 SCR 1075 [Sparrow], para 68: 'Fishing rights are not traditional property rights. They are rights held by a collective and are in keeping with the culture and existence of that group. Courts must be careful, then, to avoid the application of traditional common law concepts of property as they develop their understanding of ... the "sui generis" nature of aboriginal rights.'

${ }^{64}$ Ibid. 
customs and traditions that were integral to the distinctive culture of the group in question at the time of contact with Europeans or, for the Métis, effective European control. ${ }^{65}$ In Sappier/Gray, ${ }^{66}$ for example, the Court held that pre-contact practices, customs and traditions of the Maliseet and Mi'kmaq peoples in New Brunswick gave them an Aboriginal right to harvest wood on Crown land for domestic purposes, such as constructing houses and making furniture for themselves. In $R v$ Gladstone, ${ }^{67}$ the Court decided that the Heiltsuk people in British Columbia, based on their pre-contact practices, have a right to collect herring spawn on kelp and sell it in commercial quantities.

In Australia, reliance on the doctrine of continuity and use of Indigenous law to determine the content of Native title have not produced very positive outcomes for Indigenous peoples (McNeil, 2001b; Young, 2008; Strelein, 2009). After the Mabo decision in 1992, the High Court has regarded Native title as a divisible bundle of rights, each of which must originate in Indigenous laws and customs existing at the time of British acquisition of sovereignty and continuing substantially uninterrupted to the present day. ${ }^{68}$ Australian law post-Mabo has thus not made the distinction found in

${ }^{65}$ Van der Peet, above n29; Powley, above n28.

${ }^{66}$ Above n28.

${ }^{67}$ [1996] 2 SCR 723.

${ }^{68}$ See cases in $\mathrm{n} 37$ above, especially Ward and Yorta Yorta. For a recent interpretation of Ward, leading to a holding that the Pilki People in Western Australia have a Native title right under their traditional laws and customs to access and take resources from the area in question for any purpose, including commercial purposes, see Willis $v$ Western Australia, [2014] FCA 714. 
Canadian law between Aboriginal title as an all-encompassing property right and resource use rights based on practices, customs and traditions. Instead, a right to hunt estuarine crocodiles is as much a Native title right as a right to live on the land. ${ }^{69}$ Moreover, the dimensions of any Native title right are determined, not by possession or practices as such, but by the definition of the right in the normative system of the Indigenous people concerned. ${ }^{70}$ So even if they were in exclusive possession of land at the time of Crown sovereignty, an Indigenous people's rights extend only to the resources to which they had rights under their own legal system. ${ }^{71}$ They would not have mineral rights, for example, if their pre-sovereignty laws and customs did not provide them with these rights. $^{72}$

In addition, the High Court has refused to envisage the existence of inherent Indigenous rights that are not in relation to lands and resources. Claims to selfgovernment rights in particular have been firmly rejected. ${ }^{73}$ Native title rights therefore

${ }^{69}$ See Yanner v Eaton, (1999) 166 ALR 258 (HC); Wik Peoples v Queensland, (1996) 141 ALR 129 (HC).

${ }^{70}$ See Yorta Yorta, above n37.

${ }^{71}$ Compare Mabo, Court Order, above at n33.

${ }^{72}$ See Ward, above n37, especially para 382.

${ }^{73}$ See Walker $v$ New South Wales, (1994) 182 CLR 45; Coe v Commonwealth, (1993) 68 ALJR 110; Thorpe v Commonwealth [No 3], (1997) 71 ALJR 767; Yorta Yorta, above n37. 
appear to be narrowly proprietary - they are not territorial in the sense of including jurisdiction to make new laws after Crown acquisition of sovereignty. ${ }^{74}$

While the doctrine of continuity has also been applied in New Zealand, it has not had the negative impact seen in Australia because Māori land rights are based on tikanga Māori, encompassing both custom and usage. However, rights not otherwise extinguished were mostly converted into common law interests in the nineteenth and early twentieth centuries by the Native (now Māori) Land Court, with the result that not much communal Māori land remains (Williams, 1999; Ruru, 2009: 117-18). The New Zealand Court of Appeal has nonetheless affirmed that Māori land rights based on tikanga Māori can still exist, typically as exclusive interests equivalent to fee simple estates, or less commonly as more limited interests. ${ }^{75}$ Where Māori land rights are exclusive they apparently include rights to standing timber and mineral resources, a conclusion flowing from their equivalence to fee simple. ${ }^{76}$ They also include authority to manage the lands in accordance with tikanga Māori, authority that the Māori generally claim flows from their sovereignty as confirmed by the Treaty of Waitangi (Durie, 2005; Jones, 2013).

\section{Proof of Indigenous territorial rights}

\footnotetext{
${ }^{74}$ See Yorta Yorta, above n37, paras 43-44.

${ }^{75}$ See Ngati Apa, above n45; Young, 2008: 167-200.

${ }^{76}$ See New Zealand Maori Council v Attorney-General, [1989] 2 NZLR 142 (CA);

Tainui Maori Trust Board v Attorney-General, [1989] 2 NZLR 513 (CA), at 527-30;

Young, 2008: 180-82.
} 
When Indigenous rights are claimed in court, the onus is on the claimants to prove their rights in accordance with the rules and evidentiary standards of the dominant legal system (McNeil, 1999). This can be a formidable task, especially because much of the evidence consists of oral traditions, going back hundreds of years in some cases (Borrows, 2001; Miller, 2011). In Canada, for example, Aboriginal title depends on proof of exclusive occupation at the time the British Crown asserted sovereignty, accepted as 1713 in mainland Nova Scotia and 1846 in British Columbia. ${ }^{77}$ Acknowledging the difficulties of proof, the Supreme Court has directed trial judges to admit oral histories despite the hearsay rule and to give them the weight accorded to written documents. ${ }^{78}$ As with other testimony, judges nonetheless retain discretion over the weight given to oral histories. $^{79}$

The tests for proof of Indigenous rights vary in each nation-state, depending on their source and other factors. The test in the United States is the least onerous, as virtually any Indian use of lands can give rise to Indigenous territorial rights (Cohen, 1947). ${ }^{80}$ In 1835 Justice Baldwin expressed the Supreme Court's opinion in Mitchel v United States that Indian occupation 'was considered with reference to their habits and modes of life; their hunting-grounds were as much in their actual possession as the

${ }^{77} R v$ Marshall; $R$ v Bernard [2005] 2 SCR 220, para 71 [Marshall/Bernard];

Delgamuukw, above n23, para 145.

${ }^{78}$ Delgamuukw, above n23, paras 80-87.

${ }^{79}$ Mitchell v MNR, [2001] 1 SCR 911, para 36 [Mitchell].

${ }^{80}$ Note that proof of occupation is unnecessary where the government has recognized Indian title. For an excellent review of case law, see Kaplan, 2003. 
cleared fields of the whites, and their rights to its exclusive enjoyment in their own way and for their own purposes were as much respected' ${ }^{81}$

The American approach to occupation is clearly territorial. In United States $v$. Santa Fe Pacific Railroad, Justice Douglas observed:

Occupancy necessary to establish aboriginal possession is a question of fact to be determined as any other question of fact. If it were established as a fact that the lands in question were, or were included in, the ancestral home of the Walapais in the sense that they constituted definable territory occupied exclusively by the Walapais (as distinguished from lands wandered over by many tribes), then the Walapais had 'Indian title'. ${ }^{82}$

Tribes regarded as 'nomadic' have thus been held to have title to lands regularly used in accordance with their ways of life. ${ }^{83}$ Title also extends to 'seasonal or hunting areas over

${ }^{81} 34$ US (9 Pet) 711 at 746 (1835).

82314 US 339 (1941) [Santa Fe Pacific Railroad]. There are numerous examples of this territorial approach in Court of Claims' decisions reviewing rulings on wrongful taking of Indian lands made by the Indian Claims Commission, established in 1946 to deal with claims against the United States: see Sutton, 1985; Kaplan, 2003.

${ }^{83}$ United States v Kagama, 118 US 375 at 381 (1886); Cramer v United States, 261 US 219 at 227 (1923); Northwestern Bands of Shoshone Indians v United States, 324 US 335 
which the Indians had control even though those areas were only used intermittently. ${ }^{84}$ In keeping with the territorial approach, exercise of control is as important as actual use. In United States $v$ Seminole Indians of Florida, Justice Collins stated that 'the Government leans far too heavily in the direction of equating "occupancy" (or capacity to occupy) with actual possession, whereas the key to Indian title lies in evaluating the manner of land-use over a period of time. Physical control or dominion over the land is the dispositive criterion. ${ }^{85}$

Unlike in Canada, Indian title in the United States does not depend on occupation at the time of European or even American assertion of sovereignty. Instead, occupation 'for a long time' is sufficient (Kaplan, 2003: §3c). ${ }^{86}$ In Confederated Tribes of the Warm Springs Reservation of Oregon v United States, Justice Durfee explained that ' $[\mathrm{t}] \mathrm{he}$ time requirement, as a general rule, cannot be fixed at a specific number of years. It must be long enough to have allowed the Indians to transform the area into domestic territory so as not to make the Claims Commission Act 'an engine for creating aboriginal title in a

at 338-40 (1945); Tee-Hit-Ton Indians v United States, 120 F Supp 202 at 204 (1954, Ct Cl), affirmed 348 US 272 at 285-88 (1955) [Tee-Hit-Ton Indians USSC].

${ }^{84}$ Confederated Tribes of the Warm Springs Reservation of Oregon v United States, 177 Ct Cl 184 at 194 (1966) [Confederated Tribes].

${ }^{85} 180 \mathrm{Ct} \mathrm{Cl} 375$ at 385-86 (1967, emphasis in original) [Seminole Indians].

${ }^{86}$ Sac and Fox Tribe of Indians of Oklahoma v United States, $161 \mathrm{Ct} \mathrm{Cl} 189$ at 202 at 205-7 (1963), cert denied 375 US 921 (1963) [Sac and Fox Tribe]; United States v Pueblo of San Ildefonso, 513 F 2d 1383 at 1394 (1975, Ct Cl) [San Ildefonso]. 
tribe which itself played the role of conqueror but a few years before." ${ }^{87}$ So Indian nations could acquire title by peaceful transfer among themselves or by occupying vacant lands after American acquisition of sovereignty, ${ }^{88}$ thus shortening the timeframe for occupation and easing the burden of proof. ${ }^{89}$

Regarding exclusivity, American courts have held that two or more Indian nations can have joint title if they amicably and exclusively occupied the same territory together (Kaplan, 2003: $§ 3 b) .{ }^{90}$ In the Delgamuukw case, ${ }^{91}$ the Supreme Court suggested that this is also possible in Canada, though so far no joint title cases have been decided. This may, however, be a means for resolving some of the many overlapping land claims in British Columbia (McNeil, 2015).

The exclusive occupation at Crown sovereignty required in Canada can be established by proof of physical presence on and use of land, as well as by evidence of Aboriginal law. In Delgamuukw, Chief Justice Lamer explained that 'the source of

${ }^{87}$ Confederated Tribes, above n84, 194, quoting Sac and Fox Tribe, above n86, 206.

${ }^{88}$ See Turtle Mountain Band of Chippewa Indians v United States, 490 F 2d 935 (1974, $\mathrm{Ct} \mathrm{Cl})$ [Turtle Mountain Band].

${ }^{89}$ In Seminole Indians, above n85, 58 years were enough. In Alabama-Coushatta Tribe v United States, 28 Fed Cl 95 (1993), 30 years sufficed.

${ }^{90}$ See Santa Fe Pacific Railway, above n82; Turtle Mountain Band, above n88, 944; San Ildefonso, above n86, 1394-95; Strong v United States, 518 F 2d 556 at 561-62 (1975, Ct Cl), cert denied 423 US 1015 (1975); Uintah Ute Indians v United States, 28 Fed Cl 768 at 785, $787 \mathrm{n} 21$ (1993).

91 Above n23, para 158. 
aboriginal title appears to be grounded both in the common law and in the aboriginal perspective on land; the latter includes, but is not limited to, their systems of law. It follows that both should be taken into account in establishing the proof of occupancy. ${ }^{92}$ Physical occupation, he continued, 'may be established in a variety of ways, ranging from the construction of dwellings through cultivation and enclosure of fields to regular use of definite tracts of land for hunting, fishing or otherwise exploiting its resources. ${ }^{93}$ Relevant factors include 'the group's size, manner of life, material resources, and technological abilities, and the character of the lands claimed. ${ }^{94}$

Lamer CJ's approach to title in Delgamuukw appears to be territorial, as an Indigenous nation's land laws would normally apply to the geographical area over which the nation exercised jurisdiction. However, when the Supreme Court reconsidered the issue of proof of Aboriginal title in Marshall/Bernard, ${ }^{95}$ Chief Justice McLachlin emphasized physical occupation while virtually ignoring Aboriginal law. ${ }^{96}$ She also seems to have adopted a narrower view of the geographical extent of title, requiring proof of occupation of specific sites rather than of a larger territory (McNeil, 2006). Following this approach the British Columbia Court of Appeal in Tsilhqot'in Nation v British Columbia, involving a title claim over a large, sparsely populated area in the interior of

\footnotetext{
${ }^{92}$ Ibid, para 147.

${ }^{93} \mathrm{Ibid}$, para 149 .

${ }^{94}$ Ibid, quoting Slattery, 1987: 758.

${ }^{95}$ Above $\mathrm{n} 77$.

${ }^{96}$ Compare per LeBel and Fish JJ, ibid, concurring in result but disagreeing with McLachlin's approach.
} 
the province, held that Aboriginal title is limited to lands occupied as 'village sites, enclosed or cultivated fields' and 'definite tracts' that 'were the subject of intensive use (specific hunting, fishing, gathering, or spiritual sites). ${ }^{97}$ The Supreme Court unanimously reversed this decision and for the first time in Canada issued a declaration of Aboriginal title over the portion of the claim area where the trial judge had found that the requisite occupation had been proven. McLachlin CJ said that the Court in Marshall/Bernard 'did not reject a territorial approach, but held only (at para. 72) that there must be "proof of sufficiently regular and exclusive use" of the land in question, a requirement established in Delgamuukw. ${ }^{98}$ Summarizing the correct approach, she stated that '[o]ccupation sufficient to ground Aboriginal title is not confined to specific sites of settlement but extends to tracts of land that were regularly used for hunting, fishing or otherwise exploiting resources and over which the group exercised effective control at the time of assertion of European sovereignty. ${ }^{99}$ Regarding exclusivity, she said it 'should be understood in the sense of intention and capacity to control the land. ${ }^{100}$ One way control could be demonstrated would be by evidence that permission was required for others to enter the land: 'The fact that permission was requested and granted or refused, or that treaties were made with other groups, may show intention and capacity to control

\footnotetext{
${ }^{97}$ [2012] 3 CNLR 333, para 230.

${ }^{98}$ Tsilhqot'in Nation, above n27, para 43.

${ }^{99}$ Ibid, para 50.

${ }^{100}$ Ibid, para 48.
} 
the land. Even the lack of challenges to occupancy may support an inference of an established group's intention and capacity to control. ${ }^{, 01}$

McLachlin CJ emphasized the need to take 'a culturally sensitive approach to sufficiency of occupation based on the dual perspectives of the Aboriginal group in question - its laws, practices, size, technological ability and the character of the land claimed - and the common law notion of possession as a basis for title. ${ }^{102}$ While it is not clear from her judgment how Indigenous laws relate to proof of title, I would argue that evidence of the territorial application of these laws should establish the jurisdictional dimension of Aboriginal title (McNeil, 2012b: 750-52).

Regarding the common law notion of possession as a root of title, McLachlin adopted the opinion of Cromwell JA (as he then was) in $R v$ Marshall $^{103}$ and decided that the correct standard is that required for general occupancy, not the higher standard for adverse possession (McNeil, 1989: 197-98). 'A general occupant at common law,' she said, 'is a person asserting possession of land over which no one else has a present interest or with respect to which title is uncertain. ${ }^{104}$ Like general occupants and unlike adverse possessors, at the time of Crown sovereignty Indigenous peoples obviously were not known wrongdoers who were squatting on someone else's land (McNeil, 2012b: 758).

${ }^{101}$ Ibid.

${ }^{102}$ Ibid, para 41.

${ }^{103}$ [2004] 1 CNLR 211, paras 135-38. Justice Cromwell was appointed to the Supreme Court after deciding $R v$ Marshall, reversed in Marshall/Bernard, above $\mathrm{n} 77$. ${ }^{104}$ Tsilhqot'in Nation, above n27, para 39. 
As discussed earlier, Canadian law distinguishes Aboriginal title from rights to harvest particular resources. The test for proof of the latter was established by the Supreme Court in 1996 in Van der Peet. ${ }^{105}$ Aboriginal claimants must prove that the activity they claim a right over was 'an element of a practice, custom or tradition integral to [their] distinctive culture' at the time of European contact ${ }^{106}$ or, for the Métis, effective European control. ${ }^{107}$ In Sappier/Gray, Justice Bastarache said that '[f]lexibility is important when engaging in the Van der Peet analysis because the object is to provide cultural security and continuity for the particular aboriginal society., ${ }^{108}$ Regarding the 'integral to the distinctive culture' requirement, he elaborated:

What is meant by 'culture' is really an inquiry into the pre-contact way of life of a particular aboriginal community, including their means of survival, their socialization methods, their legal systems, and, potentially, their trading habits. The use of the word 'distinctive' as a qualifier is meant to incorporate an element of aboriginal specificity. However, 'distinctive' does not mean 'distinct', and the notion of aboriginality must not be reduced to 'racialized stereotypes of Aboriginal peoples'. 109

\footnotetext{
${ }^{105}$ Above n29.

${ }^{106}$ Ibid, para 46.

${ }^{107}$ Powley, above n28.

${ }^{108}$ Sappier/Gray, above n28, para 33.

${ }^{109}$ Ibid, para 45, quoting Borrows and Rotman, 1997: 36.
} 
As mentioned previously, the Supreme Court held that the evidence of pre-contact practices of the Mi'kmaq and Maliseet peoples established an Aboriginal right to harvest wood for domestic uses on Crown lands traditionally used for that purpose.

Unlike in Canada and the United States, in Australia proof of exclusive occupation is not enough to establish Native title; instead, a connection to the land based on traditional laws and customs is required. ${ }^{110}$ As argued above, I think this requirement stems from a misinterpretation of Justice Brennan's judgment in Mabo and incorporation of this misinterpretation into the definition of Native title in section 223(1) of the Native Title Act 1993 (McNeil, 2012a). As construed and applied by the High Court, this section necessitates proof that claimants have maintained a connection with their land through substantially uninterrupted observance of their laws and customs from Crown sovereignty to the present. ${ }^{111}$ Proof of Native title is thus virtually impossible in populated areas where connection to land and observance of traditional laws and customs have been severely interfered with. As the cause of loss of connection and observance seems to be irrelevant, ${ }^{112}$ apparently even illegal squatting - a common way of taking Indigenous land historically - could have caused loss of Native title by severing the necessary connection.

${ }^{110}$ Ward, above n37, especially paras 89-93.

${ }^{111}$ Yorta Yorta, above n37. See also De Rose [No 1], (2003) 133 FCR 325 (Full FC); De Rose v South Australia [No 2], (2005) 145 FCR 290; Northern Territory v Alyawarr, (2005) 145 FCR 442.

112 Bodney v Bennell, (2008) 167 FCR 84, paras 96-97, relying on Yorta Yorta, above n37, paras 89-90. 
The High Court's approach to Native title also necessitates proof of specific laws and customs relating to particular uses of lands and resources. ${ }^{113}$ A general system of traditional laws and customs relating to land is not sufficient unless they provide for 'rights' recognizable as such by Australian courts (Young, 2008). So unlike in Canada where historical practices alone can generate rights, in Australia practices must have been pursuant to laws and customs. ${ }^{114}$ Moreover, as previously mentioned proof of exclusive occupation does not necessarily result in all-inclusive land rights in Australia. ${ }^{115}$

In New Zealand, we have seen that Indigenous land rights are grounded in tikanga Māori, including both custom and usage. Māori land rights can thus be established by proof of custom or usage in relation to claimed land when Britain asserted sovereignty in $1840 .{ }^{116}$ If exclusive occupation is proven, the claimants have title equivalent to an inalienable fee simple estate, whereas more limited interests arise from customs or uses that did not provide for exclusive occupation. ${ }^{117}$ Moreover, unlike in Australia, proof of continuous observance of tikanga Māori from the time of British assertion of sovereignty

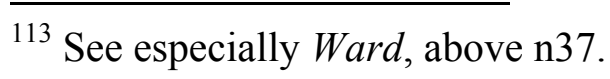

${ }^{114}$ See Mason v Tritton, (1994) 34 NSWLR 572 (NSWCA); Derschaw v Sutton, (1996) 90 A Crim R 9 (Full SCWA); Dillon v Davies, (1998) 156 ALR 142 (SC Tas). For critiques, see McNeil, 2001b: 454-58; Young, 2008: 338-42.

${ }^{115}$ Ward, above n37, especially para 382.

${ }^{116}$ Statutes also apply this common law approach: see Kauwaeranga Judgment, Native Land Court, 1870, in (1984) 14 Victoria University of Wellington Law Review 227; Ngati Apa, above n45; Ruru, 2009.

${ }^{117}$ See text at nn 75-76 above. 
to the present does not appear to be necessary (Young, 2008: 172-75). As in Canada, where title has been established as of that time, apparently it is presumed to continue until shown to have been extinguished (McNeil, 2004a).

\section{Protection of Indigenous territorial rights}

In each nation-state considered here, Indigenous rights are legally enforceable. They should therefore enjoy at least as much protection against infringement and taking as property rights of private persons. Unfortunately, this has not been so in practice and is not even the case in law in some instances. As the protections accorded these rights vis-àvis governments depend on constitutional law and vary considerably, we need to consider each country separately.

In the United States, the Supreme Court has held that Indian title could have been acquired by the European powers and the United States by conquest (McNeil, 1989: 245 n4). In fact, during the nineteenth century the United States did engage in numerous Indian wars as it expanded westward, resulting in the taking of immense areas of Indian territory. ${ }^{118}$ In situations where the taking occurred after incorporation of these Indian territories into the United States, one needs to wonder at the takings' legality. Chief Justice Marshall nonetheless took a pragmatic approach in Johnson v M'Intosh:

\footnotetext{
${ }^{118}$ While conquests were often followed by cession by treaty, the reality is that Indian nations often had no choice, as acknowledged in Tee-Hit-Ton Indians USSC, above n83, 289-90. The Indian Claims Commission did provide some redress: see n82 above.
} 
However extravagant the pretension of converting the discovery of an inhabited country into conquest may appear, if the principle has been asserted in the first instance, and afterwards sustained; if a country has been acquired and held under it; if the property of the great mass of the community originates in it, it becomes the law of the land and cannot be questioned. ${ }^{119}$

Quite possibly the power of the United States to take Indian lands by conquest could be a consequence of the quasi-independent status of the Indian nations (McNeil, 1989: 245-49). In its controversial 1955 decision in Tee-Hit-Ton Indians v United States, ${ }^{120}$ the Supreme Court held that, unless recognized by the United States, Indian title is not a property right compensable under the Constitution's Fifth Amendment. ${ }^{121}$ Justice Reed described Indian title as a 'right of occupancy [that] may be terminated and such lands fully disposed of by the sovereign itself [the United States] without any legally enforceable obligation to compensate the Indians. ${ }^{, 122} \mathrm{He}$ observed that the Tee-Hit-Ton claim 'was more a claim of sovereignty than of ownership', ${ }^{123}$ suggesting that the jurisdictional dimensions of Indian title and the political nature of the Indian nations'

${ }^{119}$ Johnson, above n6, 591.

${ }^{120}$ Above $\mathrm{n} 83$.

${ }^{121} 1$ US Stat 21, providing, inter alia, that private property shall not be taken for public use without just compensation.

${ }^{122}$ Tee-Hit-Ton Indians USSC, above n83, 279. For critiques, see Henderson, 1977;

Newton, 1980; Bloxham, 1980; McNeil, 2000b.

${ }^{123}$ Tee-Hit-Ton Indians USSC, above n83, 287. 
relationship with the United States may justify denying them the protection of the Constitution (McNeil, 1989: 259-67). ${ }^{124}$ In any case, numerous Supreme Court decisions have held that Indian territorial rights, including both jurisdiction and land rights, are subject to the plenary power of Congress and so can be taken away at any time (Kaplan, 2003: §5). ${ }^{125}$ However, the states have no such authority, as the Constitution’s Commerce Clause gives Congress exclusive jurisdiction over Indian affairs, and the Indian Trade and Intercourse Acts ${ }^{126}$ from the 1790s prohibit state acquisition of Indian lands (Clinton and Hotopp, 1979; Shattuck, 1991).

In Australia, Indigenous land rights apart from statute were not even acknowledged until the Mabo decision in $1992,{ }^{127}$ where the High Court also decided that Native title could be extinguished, not just by legislation, but by the Crown appropriating land or granting it to private persons (McNeil, 2004b; Secher, 2014: 147-

${ }^{124}$ See also Talton $v$ Mayes, 163 US 376 at 384 (1896), holding that, as Indian nations' governmental powers 'existed prior to the Constitution, they are not operated upon by the Fifth Amendment.'

${ }^{125}$ See Lone Wolf v Hitchcock, 187 US 553 (1903); Wheeler, above n16, 323; Cotton Petroleum Corporation v New Mexico, 490 US 163 at 192 (1989); South Dakota v Yankton Sioux Tribe, 522 US 329 at 343 (1998). For critiques, see Deloria, 1985: 141-60; Wilkins and Lomawaima, 2001: 98-116. In Lara, above n16, Thomas J, concurring in result, questioned the plenary power doctrine.

${ }^{126}$ Originally 1 US Stat 137 (1790). See County of Oneida v Oneida Indian Nation, 470 US 226 (1985).

${ }^{127}$ Above n32. 
96). ${ }^{128}$ Native title nonetheless enjoys some protection against state laws by the doctrine of federal paramountcy, whereby federal statutes prevail over conflicting state legislation. ${ }^{129}$ Consequently, in Mabo v Queensland [No 1] ${ }^{130}$ the High Court decided that a Queensland statute ${ }^{131}$ purporting to extinguish the land rights of the Torres Strait Islanders was invalid because it was inconsistent with the federal Racial Discrimination Act 1975 (Cth). Similarly, in Western Australia v The Commonwealth ${ }^{132}$ the Court invalidated a statute attempting to extinguish Native title in Western Australia and replace it with more vulnerable statutory rights, ${ }^{133}$ as that conflicted with the Racial Discrimination Act 1975 (Cth) and the Native Title Act 1993 (Cth). Since 1993 Native title has been governed by the complex legislative regime contained in the latter Act (Bartlett, 2014).

In New Zealand, Māori land rights are even more vulnerable, as they enjoy no constitutional protection. Unlike in Australia, there is not even the limited protection of

${ }^{128}$ Ibid, 15, 64-70, 89. See McNeil, 1996, contending that, absent unambiguous statutory authority, extinguishment by appropriation or grant violates fundamental common law principles.

${ }^{129}$ S109 of the Constitution, Commonwealth of Australia Constitution Act 1900, 63 \& 64 Vic, c12 (UK), s9.

130 (1988) 166 CLR 186.

${ }^{131}$ Queensland Coast Islands Declaratory Act, 1985 (Q1d), enacted to forestall the proceedings that led to Mabo, above n32. See Keon-Cohen, I, 113-20.

132 (1995) 128 ALR 1.

${ }^{133}$ Land (Titles and Traditional Usage) Act, 1993 (WA). 
federal paramountcy because New Zealand is a unitary nation-state. Parliament can rely on the common law doctrine of parliamentary sovereignty and enact laws that infringe and even extinguish Māori rights. ${ }^{134}$ This in fact happened as recently as 2004 when Parliament passed the Foreshore and Seabed Act (since repealed), ${ }^{135}$ extinguishing any exclusive Māori rights to the foreshore and seabed and restricting more limited Māori rights to engage in practices and uses in relation thereto (Charters and Erueti, 2007). Protection of Māori rights against legislation is therefore not constitutional but political, provided to some extent by Māori representation in Parliament. ${ }^{136}$

Of the four nation-states, only in Canada are Indigenous rights explicitly protected by the Constitution. Prior to 1982, the Canadian Parliament had the authority to extinguish these rights by clear and plain legislation, but that changed when section 35(1) of the Constitution Act, 1982 was enacted, providing that ' $[t]$ he existing aboriginal and treaty rights of the aboriginal peoples of Canada are hereby recognized and affirmed'. ${ }^{137}$ The Supreme Court has nonetheless held that Aboriginal and treaty rights, including land rights, can still be infringed, though not extinguished, by legislation if the infringement

${ }^{134}$ For the classic exposition of this doctrine, see Dicey, 1885.

${ }^{135} 2004$ No 93, replaced by the Marine and Coastal Area (Takutai Moana) Act, 2011 No 3 , ss 5 and 6 of which repealed the 2004 Act and restored the customary interests extinguished by it.

${ }^{136}$ Governed by the Electoral Act of 1993. The number of Māori seats is determined by the Māori electoral population. See New Zealand Parliament, Research Paper, 2009. ${ }^{137}$ Above n1. See Van der Peet, above n29, para 28; Mitchell, above n79, para 11. 
can be justified (McNeil, 2004b). ${ }^{138}$ Justification involves proof by the Crown of a valid legislative objective and respect for its fiduciary obligations to the Indigenous people concerned. Specifically, the Crown must have consulted with them in good faith to try to reach an agreement, have infringed their rights as little as possible to achieve its objective, and have paid compensation where the infringement has an economic impact. $^{139}$

Prior to the Supreme Court's recent decision in Tsilhqot'in Nation, ${ }^{140}$ there was doubt over whether provincial legislatures had the constitutional authority to infringe Aboriginal rights, given that these rights are within the core of exclusive federal jurisdiction over 'Indians, and Lands reserved for the Indians'(McNeil, 1998; Wilkins, 1999). ${ }^{141}$ In that case, the Court held that the provinces do have authority to infringe these rights, provided the justification test is met. However, as mentioned earlier, infringements 'cannot be justified if they would substantially deprive future generations of the benefit of the land. ${ }^{142}$ Also, as compensation must be paid for infringements that have an economic impact, provinces should think twice about proceeding with resource

${ }^{138}$ Sparrow, above n63.

${ }^{139}$ Ibid; Delgamuukw, above23, paras 106-69; Tsilhqot'in Nation, above n27, paras 7688.

${ }^{140}$ Above n27.

${ }^{141}$ Constitution Act, 1867, 30 \& 31 Vic, c12, s91(24). See Delgamuukw, above n23, paras 173-81.

${ }^{142}$ Tsilhqot'in Nation, above n27, para 86. 
development without the consent of the Indigenous people who have a claim to the land (McNeil, 2005: 460).

\section{Conclusions}

We have seen that Indigenous land rights have been judicially acknowledged in all four nation-states, though belatedly in Australia. They are property rights, ${ }^{143}$ ranging from ownership equivalent to an inalienable fee simple to more limited rights to resources that were traditionally used in accordance with Indigenous ways of life. Only in the United States, however, have Indigenous rights been explicitly accepted by the Supreme Court as territorial, encompassing jurisdiction as well as exclusive land rights, with the downside that they are not protected against taking by the United States because they are outside the scope of the Constitution and subject to the plenary power of Congress.

In Australia, the High Court has been unwilling to attribute any jurisdictional authority to the Indigenous peoples, making this a matter of negotiated agreement. In New Zealand, debate continues over the impact of the Treaty of Waitangi on Māori jurisdiction, resulting in divergent opinions (Belgrave et al, 2005). In Canada, the Supreme Court has studiously avoided the issue, preferring that it be dealt with in the

\footnotetext{
${ }^{143}$ Though in the United States they are only property rights for constitutional purposes if recognized: see text at nn 120-24 above.
} 
political arena. ${ }^{144}$ This has been happening slowly in modern land claims agreements, such as the Nisga'a Final Agreement of 1998, ${ }^{145}$ but if Justice Williamson was correct in the Campbell decision (as I think he was: McNeil, 2007b), ${ }^{146}$ then these agreements do not create self-government rights; rather, they acknowledge and define the existing inherent jurisdiction of Indigenous peoples over their territories. Canada is thus moving in the direction of the United States, though more in the political arena than in the courts. However, without the impetus of court decisions since the recognition of Indigenous rights in the Constitution in 1982, this probably would not be happening.

${ }^{144}$ See Delgamuukw, above n23. In $R v$ Pamajewon, [1996] 2 SCR 821, the one case dealing with a self-government claim directly, the Court made it so hard to prove that the matter necessarily got forced back to the political arena.

${ }^{145}$ Online: http://www.nnkn.ca/files/u28/nis-eng.pdf.

${ }^{146}$ Campbell, above n56. 


\section{Bibliography}

Barsh, Russel Lawrence, 2004. 'Indigenous Rights and the Lex Loci in British Imperial Law', in Kerry Wilkins, ed, Advancing Aboriginal Claims: Visions/Strategies/Directions (Saskatoon: Purich Publishing), 91-126

Barsh, Russel Lawrence, and James Youngblood Henderson, 1997. 'The Supreme Court's Van der Peet Trilogy: Naive Imperialism and Ropes of Sand', 42 McGill Law Journal 993-1009

Bartlett, Richard H, 2014. Native Title in Australia, 3rd ed (Chatswood, NSW: LexisNexis Australia)

Belgrave, Michael, Merata Kawharu and David Williams, eds, 2005. Waitangi Revisited: Perspectives on the Treaty of Waitangi (South Melbourne: Oxford University Press)

Bloxham, Steven John, 1980. 'Aboriginal Title, Alaskan Native Property Rights, and the Case of the Tee-Hit-Ton Indians', 8 American Indian Law Review 299-331

Borrows, John, 1997. 'Frozen Rights in Canada: Constitutional Interpretation and the Trickster', 22 American Indian Law Review 37-64

Borrows, John, 2001. 'Listening for a Change: The Courts and Oral Traditions', 39 Osgoode Hall Law Journal 1-38

Borrows, John, 2010. Canada's Indigenous Constitution (Toronto: University of Toronto Press)

Borrows, John, and Leonard I Rotman, 1997, 36. 'The Sui Generis Nature of Aboriginal Rights: Does it Make a Difference?' 36 Alberta Law Review 9-45

Brownlie, Ian, 2003. Principles of Public International Law, 6th ed (Oxford: Clarendon Press) 
Charters, Claire, and Andrew Erueti, eds, 2007. Māori Property Rights in the Foreshore and Seabed: The Last Frontier (Wellington: Victoria University Press)

Chartrand, Paul LAH, ed, 2002. Who Are Canada's Aboriginal Peoples? Recognition, Definition, and Jurisdiction (Saskatoon: Purich Publishing)

Cheng, Chilwin Chienhan, 1997. 'Touring the Museum: A Comment on R. v. Van der Peet', 55 University of Toronto Faculty of Law Review 419-34

Clinton, Robert N, 2002. 'There Is No Federal Supremacy Clause for Indian Tribes', 34 Arizona State Law Journal 113-260

Clinton, Robert N, and Margaret Tobey Hotopp, 1979. 'Judicial Enforcement of the Federal Restraints on Alienation of Indian Land: The Origins of the Eastern Land Claims', 31 Maine Law Review 17-90

Cohen, Felix S, 1947. 'Original Indian Title', 32 Minnesota Law Review 28-59

Deloria, Vine, Jr, 1985. Behind the Trail of Broken Treaties: An Indian Declaration of Independence (Austin: University of Texas Press)

Dicey, AV, 1885. Lectures Introductory to the Study of the Law of the Constitution (London: Macmillan and Co)

Durie, Mason, 2005. 'Tino Rangatiratanga', in Michael Belgrave, Merata Kawharu and David Williams, eds, Waitangi Revisited: Perspectives on the Treaty of Waitangi (South Melbourne: Oxford University Press)

Duthu, N Bruce, 1994. 'Implicit Divestiture of Tribal Powers: Locating Legitimate Sources of Authority in Indian Country', 19 American Indian Law Review 353-402 Frickey, Philip P,1999. 'A Common Law for Our Age of Colonialism: The Judicial Divestiture of Indian Tribal Authority over Nonmembers', 109 Yale Law Journal 1-85 
Goebel, Julius, Jr, 1927. The Struggle for the Falkland Islands: A Study in Legal and Diplomatic History (reissued Port Washington, NY: Kennikat Press, 1971)

Henderson, J Youngblood, 1977. 'Unraveling the Riddle of Indian Title', 5 American Indian Law Review 75-137

Jones, Carwyn, 2013. The Treaty of Waitangi Settlement Process in Māori Legal History, $\mathrm{PhD}$ dissertation, University of Victoria Faculty of Law

Kaplan, Michael J, 2003. 'Proof and Extinguishment of Aboriginal Title to Indian Lands' LEXSEE 41 American Law Reports Federal 425

Keon-Cohen, Bryan, 2011. Mabo in the Courts: Islander Tradition to Native Title: A Memoir, 2 vols (North Melbourne: Australian Scholarly Publishing)

La Velle, John P, 2006. 'Implicit Divestiture Reconsidered: Outtakes from the Cohen's Handbook Cutting-Room Floor', 38 Connecticut Law Review 731-76

Levy, Jacob T, 2013. 'Three Perversities of Indian Law', in Lisa Ford and Tim Rowse, eds, Between Indigenous and Settler Governance (Abingdon, UK: Routledge), 148-61

Lindley, MF, 1926. The Acquisition and Government of Backward Territory in International Law (London: Longmans, Green \& Co)

McHugh, Paul, 1991. The Mãori Magna Carta: New Zealand Law and the Treaty of Waitangi (Auckland: Oxford University Press)

McNair, Lord [Arnold Duncan], 1965. The Law of Treaties (Oxford: Clarendon Press)

McNeil, Kent, 1989. Common Law Aboriginal Title (Oxford: Clarendon Press)

McNeil, Kent, 1996. 'Racial Discrimination and Unilateral Extinguishment of Native Title', 1 Australian Indigenous Law Reporter 181-221, reprinted in Kent McNeil, 
Emerging Justice? Essays on Indigenous Rights in Canada and Australia (Saskatoon: University of Saskatchewan Native Law Centre, 2001), 357-408

McNeil, Kent, 1998. 'Aboriginal Title and the Division of Powers: Rethinking Federal and Provincial Jurisdiction', 61 Saskatchewan Law Review 431-65, reprinted in Kent McNeil, Emerging Justice? Essays on Indigenous Rights in Canada and Australia (Saskatoon: University of Saskatchewan Native Law Centre, 2001), 249-91

McNeil, Kent, 1999. 'The Onus of Proof of Aboriginal Title', 37 Osgoode Hall Law Journal 775-803

McNeil, Kent, 2000a. 'Sovereignty on the Northern Plains: Indian, European, American and Canadian Claims', 39:3 Journal of the West 10-18

McNeil, Kent, 2000b. 'How the New Deal Became a Raw Deal for Native Americans: The Tee-Hit-Ton Alaska Decision and the Denial of Fifth Amendment Protection to Indian Land Title', unpublished paper delivered at the Western History Association's 40th Annual Conference, San Antonio, Texas, on file with author

McNeil, Kent, 2001a. 'The Post-Delgamuukw Nature and Content of Aboriginal Title', in Kent McNeil, Emerging Justice? Essays on Indigenous Rights in Canada and Australia (Saskatoon: University of Saskatchewan Native Law Centre), 102-35

McNeil, Kent, 2001b. 'The Relevance of Traditional Laws and Customs to the Existence and Content of Native Title at Common Law', in Kent McNeil, Emerging Justice? Essays on Indigenous Rights in Canada and Australia (Saskatoon: University of Saskatchewan Native Law Centre), 416-63

McNeil, Kent, 2002. 'Self-Government and the Inalienability of Aboriginal Title', 47 McGill Law Journal 473-510 
McNeil, Kent, 2004a. 'Continuity of Aboriginal Rights', in Kerry Wilkins, ed, Advancing Aboriginal Claims: Visions/Strategies/Directions (Saskatoon: Purich Publishing), 127-50 McNeil, Kent, 2004b. 'The Vulnerability of Indigenous Land Rights in Australia and Canada', 42 Osgoode Hall Law Journal 271-301

McNeil, Kent, 2005. 'Aboriginal Rights, Resource development, and the Source of the Provincial Duty to Consult in Haida Nation and Taku River', 29 Supreme Court Law Review (2d) 447-60

McNeil, Kent, 2006. 'Aboriginal Title and the Supreme Court: What's Happening?' 69 Saskatchewan Law Review 281-308

McNeil, Kent, 2007a. 'Legal Rights and Legislative Wrongs: Māori Claims to the Foreshore and Seabed', in Claire Charters and Andrew Erueti, eds, Māori Property Rights in the Foreshore and Seabed: The Last Frontier (Wellington: Victoria University Press), 83-118

McNeil, Kent, 2007b. 'Judicial Approaches to Self-Government since Calder: Searching for Doctrinal Coherence', in Hamar Foster, Heather Raven and Jeremy Webber, eds, Let Right Be Done: Aboriginal Title, the Calder Case, and the Future of Indigenous Rights (Vancouver: UBC Press), 129-52

McNeil, Kent, 2007c. 'The Jurisdiction of inherent Right Aboriginal Governments', (North Vancouver, BC: Centre for First Nations Governance), online: http://fngovernance.org/ncfng_research/kent_mcneil.pdf McNeil, Kent, 2012a. 'Mabo Misinterpreted: The Unfortunate Legacy of Legislative Distortion of Justice Brennan's Judgment', in Mick Dodson, ed, The Limits of Change: 
Mabo and Native Title 20 Years On (Canberra: Australian Institute of Aboriginal and Torres Strait Islanders Studies), 226-35

McNeil, Kent, 2012b. 'Aboriginal Title in Canada: Site-Specific or Territorial?' 91 Canadian Bar Review 745-61

McNeil, Kent, 2013a. 'Indigenous Nations and the Legal Relativity of European Claims to Territorial Sovereignty in North America', in Sandra Tomsons and Lorraine Mayer, eds, Philosophy and Aboriginal Rights: Critical Dialogues (Don Mills, Ontario: Oxford University Press), 242-53

McNeil, Kent, 2013b. 'Indigenous Land Rights and Self-Government: Inseparable Entitlements', in Lisa Ford and Tim Rowse, eds, Between Indigenous and Settler Governance (Abingdon, UK: Routledge), 135-47

McNeil, Kent, 2015. 'Exclusive Occupation and Joint Aboriginal Title', forthcoming, University of British Columbia Law Review

McNeil, Kent, and David Yarrow, 2007. 'Has Constitutional Recognition of Aboriginal Rights Adversely Affected Their Definition?”, 37 Supreme Court Law Review (2 $\left.{ }^{\text {nd }}\right)$ 177211

Miller, Bruce Granville, 2011. Oral History on Trial: Recognizing Aboriginal Narratives in the Courts (Vancouver: UBC Press)

Miller, Robert J, Jacinta Ruru, Larissa Berhendt and Tracey Lindberg, 2010. Discovering Indigenous Lands: The Doctrine of Discovery in the English Colonies (Oxford: Oxford University Press)

Morse, Bradford W, 1997. 'Permafrost Rights: Aboriginal Self-Government and the Supreme Court in R. v. Pamajewon', 42 McGill Law Journal 1011-42 
Napoleon, Valerie Ruth, 2009. Ayook: Gitksan Legal Order, Law, and Legal Theory, $\mathrm{PhD}$ dissertation, University of Victoria Faculty of Law

Newton, Nell Jessup, 1980. 'At the Whim of the Sovereign: Aboriginal Title

Reconsidered', 31 Hastings Law Journal 1215-85

Newton, Nell Jessup et al, eds, 2012. Cohen's Handbook of Federal Indian Law 2012

Edition, Newark: LexisNexis

New Zealand Parliament, Research Paper, 2009. 'The Origins of the Māori Seats'

(Wellington: Parliamentary Library), online: http://www.parliament.nz/en-nz/parlsupport/research-papers/00PLLawRP03141/origins-of-the-māori-seats

Norgren, Jill, 1996. The Cherokee Cases: The Confrontation of Law and Politics (New York: McGraw-Hill)

O’Connell, DP, 1967. State Succession in Municipal Law and International Law, 2 vols (Cambridge: Cambridge University Press)

Orange, Claudia, 2004. An Illustrated History of the Treaty of Waitangi (Wellington, NZ: Bridget Williams Books)

Otis, Delos Sacket, 1973. The Dawes Act and the Allotment of Indian Lands, edited by Francis Paul Prucha (Norman: University of Oklahoma Press)

Prucha, Francis Paul, 1976. American Indian Policy in Crisis: Christian Reformers and the Indian, 1865-1900 (Norman: University of Oklahoma Press)

Robertson, Lindsay G, 2005. Conquest by Law: How the Discovery of America Dispossessed Indigenous Peoples of Their Lands (New York: Oxford University Press) 
Ruru, Jacinta, 2009. 'The Māori Encounter with Aotearoa: New Zealand's Legal

System', in Benjamin J Richardson, Shin Imai and Kent McNeil, eds, Indigenous Peoples and the Law: Comparative and Critical Perspectives (Oxford: Hart Publishing), 111-33

Russell, Peter H, 2005. Recognizing Aboriginal Title: The Mabo Case and Indigenous Resistance to English-Settler Colonialism (Toronto: University of Toronto Press)

Secher, Ulla, 2014. Aboriginal Customary Law: A Source of Common Law Title to Land (Oxford: Hart Publishing)

Seed, Patricia, 1995. Ceremonies of Possession in European Conquest of the New World, 1492-1640 (Cambridge: Cambridge University Press)

Shattuck, George C, 1991. The Oneida Land Claims: A Legal History (Syracuse:

Syracuse University Press)

Slattery, Brian, 1987. 'Understanding Aboriginal Rights', 66 Canadian Bar Review 72783

Slattery, Brian, 1991. 'Aboriginal Sovereignty and Imperial Claims', 29 Osgoode Hall Law Journal 681-703

Slattery, Brian, 2005. 'Paper Empires: The Legal Dimensions of French and English Ventures in North America' in John McLaren, AR Buck and Nancy E Wright, eds, Despotic Dominion: Property Rights in British Settler Societies (Vancouver: UBC Press) 50-78

Strelein, Lisa, 2009. Compromised Jurisprudence: Native Title Cases Since Mabo, $2^{\text {nd }}$ ed (Canberra: Aboriginal Studies Press)

Sutton, Imre, ed, 1985. Irredeemable America: The Indians' Estate and Land Claims (Albuquerque: University of New Mexico Press) 
Walters, Mark D, 1999. 'The “Golden Thread” of Continuity: Aboriginal Customs at Common Law and under the Constitution Act, 1982', 44 McGill Law Journal 711-52

Walters, Mark D, 2006. 'The Morality of Aboriginal Law', 31 Queen's Law Journal 470520

Wilkins, Kerry, 1999. 'Of Provinces and Section 35 Rights', 22 Dalhousie Law Journal $185-235$

Wilkins, David E, and K Tsiana Lomawaima, 2001. Uneven Ground: American Indian Sovereignty and Federal Law (Norman: University of Oklahoma Press)

Williams, David V, 1999. 'Te Kooti Tango Whenua': The Native Land Court 1864-1909

(Wellington: Huia Publishers)

Williams, Robert A, Jr, 1990. The American Indian in Western Legal Thought: The Discourses of Conquest (New York: Oxford University Press)

Young, Simon, 2008. The Trouble with Tradition: Native Title and Cultural Change (Leichhardt, NSW: Federation Press) 